\title{
Winter recovery in Sweden of a Dutch Blackcap Sylvia atricapilla
}

\author{
Vinterkontroll i Sverige av en nederländsk svarthätta Sylvia atricapilla
}

ANDERS TENGHOLM, JOHAN TENGHOLM \& ROBERT EKBLOM

Abstract

\begin{abstract}
In February 2018, a European Blackcap Sylvia atricapilla that had been ringed as a yearling in the Netherlands in the previous autumn was trapped in Uppsala, Sweden $\left(59.8^{\circ} \mathrm{N}\right)$. Winter records of Blackcaps are not uncommon in Sweden but this is the first recovery of a bird with documented southern origin. The finding is in line with reports that a relatively high proportion of ringed Blackcaps is recovered in the same autumn north of the ringing site, and that the fraction of short-winged Blackcaps of presumed southern origin increases late in the season at Swedish bird observatories. Although the present record provides evidence that Blackcaps wintering in Sweden may originate from Continental Europe, it
\end{abstract}

appears unlikely that the Blackcap will be able to evolve a new migration pattern, similar to the population of Continental Blackcaps wintering in Britain, because few Blackcaps seem to survive the Swedish winter.

Anders Tengholm, Bergagatan 32, SE-752 39 Uppsala, Sweden.E-mail: anders.tengholm@gmail.com Johan Tengholm, Bergagatan 32, SE-752 39 Uppsala, Sweden

Robert Ekblom, Department of Evolutionary Biology, Evolutionary Biology Centre, Uppsala University, Norbyvägen 18D, SE-752 36 Uppsala, Sweden

Received 26 October 2018, Accepted 7 November 2018, Editor: Sören Svensson

The European Blackcap Sylvia atricapilla shows a complex and interesting migration pattern that has been subject to many studies (see e.g. Berthold et al. 1992, Fransson \& Stolt 1993, Helbig 1994, Bengtsson et al. 2009, Hiemer et al. 2018). In the Mediterranean area, Blackcaps are largely resident, while birds in central and northern Europe migrate in a southern direction. Continental Blackcaps breeding west of approximately the $12^{\circ} \mathrm{E}$ meridian mostly take a southwestern route, whereas more eastern birds move towards southeast (Fransson, 2014). The majority of the Blackcaps in southern Sweden are believed to spend the winter in the Mediterranean area but birds from middle and northern Scandinavia likely winter in Africa south of Sahara (Fransson \& Hall-Karlsson 2008). However, it is well known that some Blackcaps stay in northern and northwestern Europe during the winter. The number of wintering Blackcaps in Britain has increased dramatically over a time span of just a few decades (Berthold et al. 1992, Helbig 1994). There is an increased number of winter records of Blackcaps also in Sweden, where the birds regularly are observed in gardens, often at feeding tables (Fransson \& Stolt 1994).
There is evidence to suggest that Blackcaps on the European continent show movements in a northwestern to northern direction in the late autumn (Berthold et al. 1992, Fransson \& Stolt 1993, Bengtsson et al. 2009). Ringing data, recently supported by geolocator studies (Hiemer et al. 2018), show that Blackcaps wintering in Britain have a continental origin. Blackcaps wintering in Scandinavia may also originate from continental populations. Bengtsson et al. (2009) reported that as many as $17 \%$ of Blackcaps ringed in Sweden and recovered the same autumn are found north of the ringing site, a number that much exceeds that for other comparable species. Moreover, the average wing length of Blackcaps ringed at Scandinavian bird observatories in the autumn decreases in the later part of the season, which has been interpreted as an influx of birds originating from more southern populations with shorter wings (Bengtsson et al. 2009). Although these observations support the hypothesis that Blackcaps wintering in Sweden originate from the continental population, direct evidence from ringing recoveries in the winter has been lacking.

On January 27, 2018, two of the authors observed 


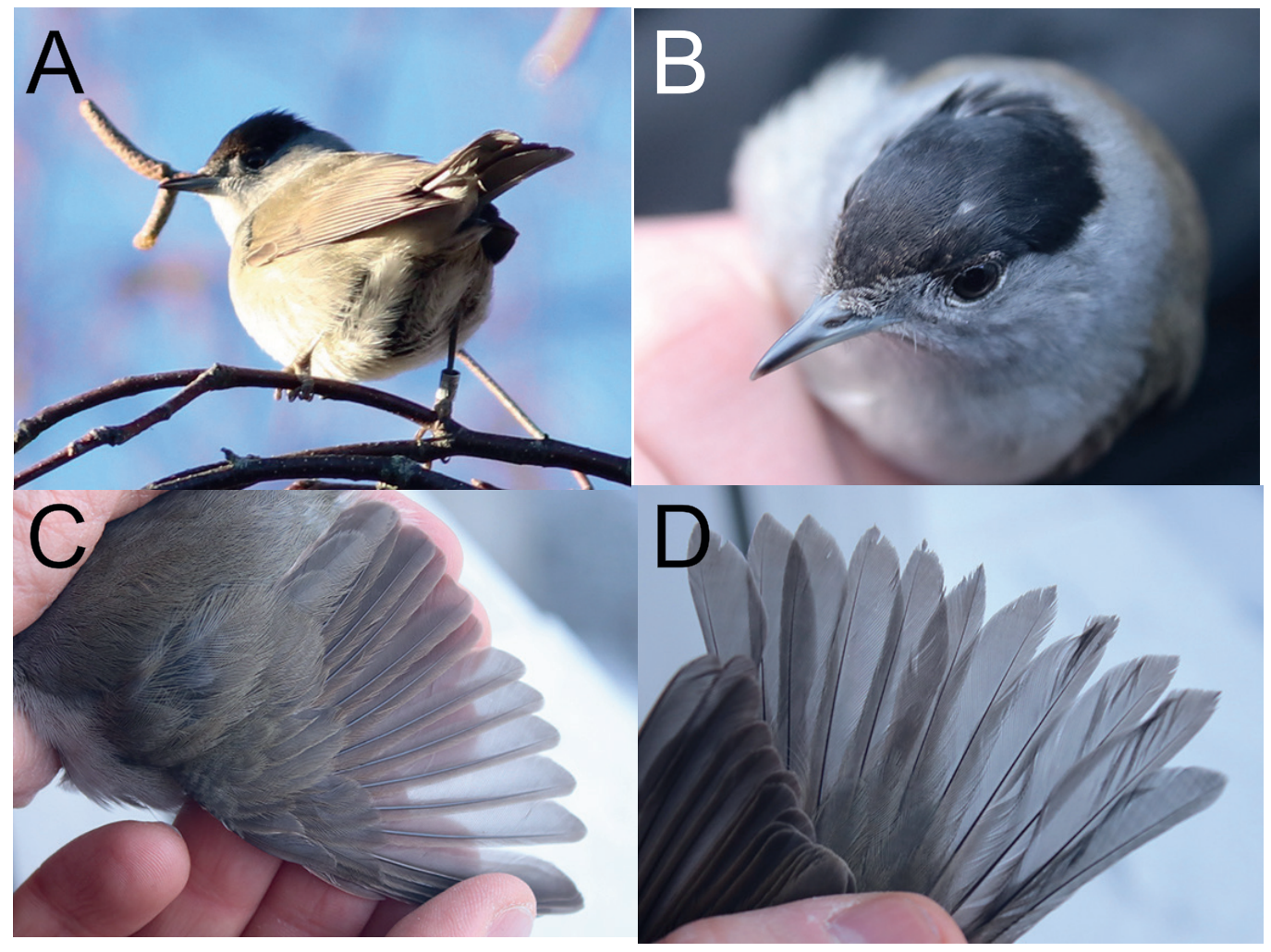

Figure 1. Photos of the male Blackcap found and captured in Uppsala, January-February 2018. The first field observation revealed that the bird was ringed (A). The brown feathers on the forehead (A and B), unmoulted carpal and primary coverts (C) and pointed tail feathers (D) demonstrated that it was in its second calendar year (2cy).

Foton av den hane av svarthätta som upptäcktes och fångades $i$ Uppsala, januari-februari 2018. Första fältobservationen avslöjade att fågeln var ringmärkt (A). De bruna fjädrarna på pannan (A och B), oruggade karpal-och handtäckare (C) och spetsiga stjärtfjädrar (D) visar att den var på sitt andra kalenderår (2cy).

a male Blackcap in their own garden in a residential neighbourhood in Uppsala, Sweden $\left(59.8491^{\circ} \mathrm{N}\right.$, $\left.17.6151^{\circ} \mathrm{E}\right)$. Photographs taken for documentation purposes showed that the bird was ringed (Figure 1a). It was observed again briefly on the following day. After two weeks without observations, the bird reappeared and was now relatively stationary close to a feeding table, foraging on apples and sunflower seeds. It was decided to make an attempt to catch it to be able to read the ring number. Accordingly, the bird was caught with a mist net on February 17, and it turned out to be a 2cy male carrying a Dutch ring (Figure $1 \mathrm{~b}-\mathrm{d}$ ). The wing length was $75 \mathrm{~mm}$, which is below the average for Blackcaps ringed in Sweden during the autumn (Bengtsson et al. 2009). The bird was in good condition with a fat score of 3 and a weight of $21 \mathrm{~g}$. It was observed again on the following day but not later despite careful sur- veillance of the garden, and the ultimate fate of the bird remains unknown.

The Blackcap had been ringed as a 1cy male on September 25, 2017, on the West Frisian island Schiermonnikoog in the Netherlands $(53.48 \mathrm{~N}$, $6.18 \mathrm{E}$ ). The recovery was thus made after 145 days, during which the bird had moved $992 \mathrm{~km}$ towards northeast $\left(40^{\circ}\right)$. It fits well into the overall pattern of records of foreign ringed Blackcaps recovered the same autumn in Sweden (Figure 2; see also Bengtsson et al. 2009 and Fransson 2014). However, the record is particularly interesting in that it is the first recovery in the midwinter period January-February. The latest recovery previously noted was a Belgian ringed bird found dead in Strömsund in northern Sweden on November 26 and a Czech bird dead in Arjeplog, even further north, on November 4. It should be noted that not all Swedish 


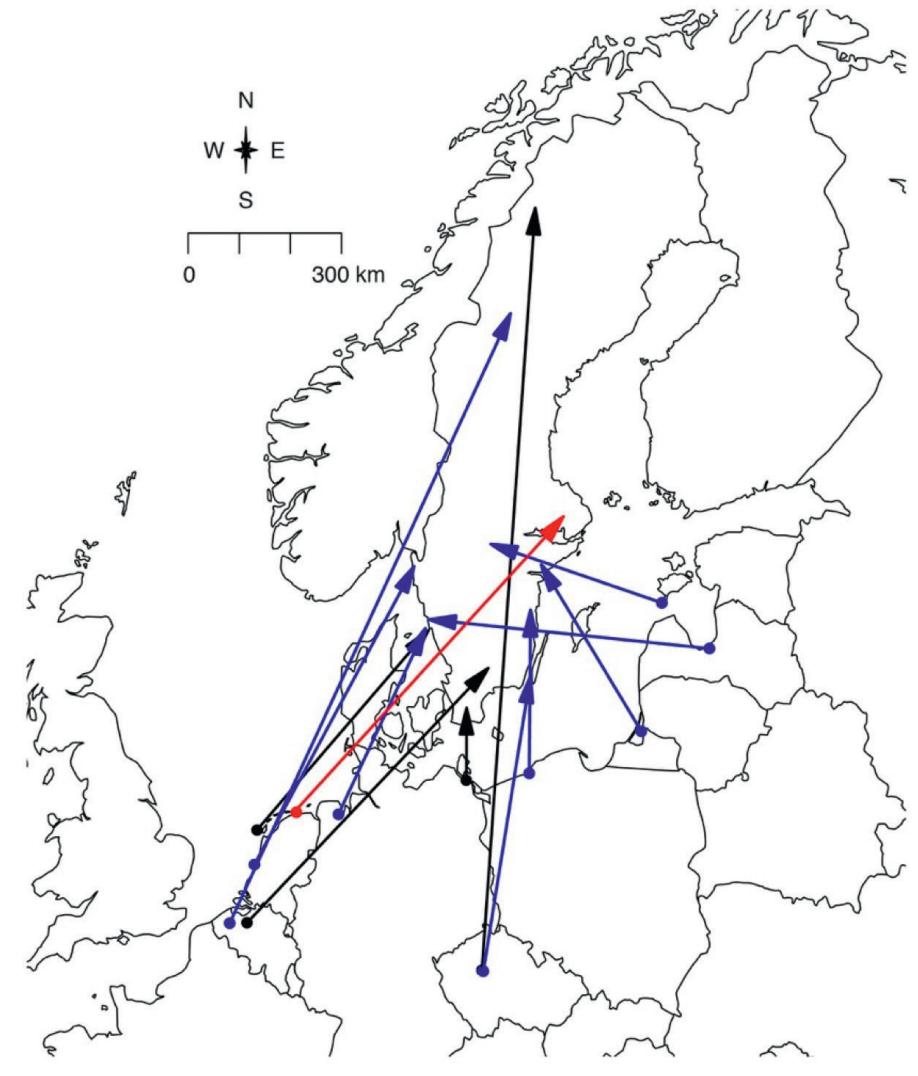

Figure 2. Swedish ringing recoveries (1994-2018) of continental European Blackcaps that have moved north during autumn migration. The red arrow represent the current case, black arrows represent cases already included in Bengtsson et al. 2009, and blue arrows represent cases since 2010. Svenska kontroller (mellan 1994 och 2018) av svarthättor som ringmärkts $i$ kontinentala Europa och rört sig norrut under höstflyttningen. Den röda pilen representerar det aktuella fyndet, svarta pilar representerar de fynd som inkluderades redan $i$ Bengtsson et al. (2009) och blåa pilar representerar fynd som gjorts sedan 2010. recoveries of foreign ringed Blackcaps in the late autumn concern birds with continental origin. Accordingly, there are records on December 1 from Slite, Gotland, and November 4 from Halmstad, Swedish southwestern coast, of Blackcaps ringed in Norwegian Telemark and Vestfold, respectively, probably reflecting ongoing late migration along the expected regular southeastern route.)

It is obviously impossible to draw any general conclusions from a single record and it remains unclear if the phenomenon reflects an established migration strategy or just reverse migration of disoriented birds. The increased number of wintering Blackcaps in Britain has been taken to indicate that a new migration strategy is being established as a result of micro-evolutionary adaptation (Berthold 1995). One argument is that the migration direction is genetically programmed (Helbig 1991) and orientation experiments with the offspring of British wintering Blackcaps bred in captivity showed that they migrated towards west-northwest, genetically distinct from the southwestern direction of British populations and the majority of the westernmost continental European Blackcaps (Berthold et al. 1992). This development has likely been favoured by increasing winter temperatures and increased food availability at garden feeding tables (Plummer et al. 2015).

Blackcaps wintering in Sweden could in principle reflect reverse migration. As pointed out by Fransson (2014), a $180^{\circ}$ misorientation would direct both the populations of southwestern and southeastern migrants from continental Europe to Sweden. However, the occurrence of Blackcaps migrating north greatly exceeds that for other comparable species (Bengtsson et al. 2009). The advantage with a northern autumn migration is far from obvious, though. A shorter migration distance and earlier arrival at the breeding territories may potentially increase breeding success. On the other hand, the survival of Blackcaps during the winter in Sweden is probably low, as indicated by a declining number of observations throughout the winter (Fransson \& Stolt 1994). Additional recoveries and more detailed information about wintering occurrence in the Nordic countries will be required to 
clarify the Blackcap's fascinating but elusive migration behaviour.

In summary, we have reported about the first winter recovery of a Dutch Blackcap in Sweden. This record provides direct support for the notion that at least some of the Blackcaps wintering in Sweden have a southern origin.

\section{Acknowledgements}

Permission to catch and ring the bird in this study was granted by the Swedish Bird Ringing Centre (ringer licence 599). The authors thank Thord Fransson at the Bird Ringing Centre, Swedish Natural History Museum, Stockholm for valuable discussions and for providing unpublished information about Blackcap ringing recoveries.

\section{References}

Bengtsson, D., Fransson, T. \& Røer, J.E. 2009. Occurrence of Continental Blackcaps Sylvia atricapilla in northern Europe. Ornis Svecica 19: 41-49.

Berthold, P. 1995. Microevolution of migratory behaviour illustrated by the Blackcap Sylvia atricapilla. Bird Study 42: 89-100.

Berthold, P., Helbig, A.J., Mohr, G. \& Querner, U. 1992. Rapid microevolution of migratory behaviour in a wild bird species. Nature 360: 668-669.

Fransson, T. 2014. Svarthättor som flyttar norrut på hösten. Ringinform 2014: 10-11.

Fransson, T. \& Hall-Karlsson, S. 2008. Svensk Ringmärkningsatlas Vol 3. Stockholm.

Fransson, T. \& Stolt, B.-O. 1993. Is there an autumn migration of Blackcaps (Sylvia atricapilla) into northern Europe? Vogelwarte 37: 89-95.

Fransson, T. \& Stolt, B.-O. 1994. The wintering of Blackcaps Sylvia atricapilla in Sweden. Ornis Svecica 4: 105-112.

Helbig, A.J. 1991. Inheritance of migratory direction in a bird species: a cross-breeding experiment with SE- and SW-migrating blackcaps (Sylvia atricapilla). Behavioral Ecology and Sociobiology 28: 9-12.
Helbig, A.J. 1994. Genetic basis and evolutionary change of migratory directions in a European Passerine migrant Sylvia atricapilla. Ostrich 65: 151-159.

Hiemer, D., Salewski, V., Fiedler, W., Hahn, S. \& Lisovski, S. 2018. First tracks of individual Blackcaps suggest a complex migration pattern. Journal of Ornithology 159: 205-210.

Plummer, K.E., Siriwardena, G.M., Conway, G.J., Risely, K. \& Toms, M.P. 2015. Is supplementary feeding in gardens a driver of evolutionary change in a migratory bird species? Global Change Biology 21: 4353-4363.

\section{Sammanfattning}

I slutet av januari 2018 observerades en ringmärkt svarthätta Sylvia atricapilla i en trädgård i Uppsala. Fågeln infångades och visade sig vara märkt som årsunge i Nederländerna föregående höst. Vinterobservationer av arten är inte ovanliga i Sverige men fyndet är det första av en i Sverige övervintrande individ med dokumenterat sydligt ursprung. Fyndet bekräftar den bild från ringmärkningsdata som visar att en relativt hög andel svarthättor som märkts på hösten och som kontrollerats senare samma höst har rört sig norrut och att skandinaviska fågelstationer under senhösten fångar en ökande andel kortvingade svarthättor av förmodat sydligt ursprung. Det är relativt väletablerat att en population av kontinentaleuropeiska svarthättor under kort tid har etablerat nya flyttningsvanor och rör sig åt nordväst för att övervintra i Storbritannien. Det återstår att klarlägga om nordliga rörelser av kontinentala svarthättor till Sverige under hösten avspeglar någon liknande mikroevolutionär process, men då vinteröverlevnaden sannolikt är låg kan det i stället röra sig om omvänd flyttning av felorienterade fåglar. Oavsett bakomliggande orsaker visar det aktuella fyndet att åtminstone en del av de svarthättor som uppträder i Sverige på vintern har inkommit söderifrån. 